\title{
The role of satisfaction as a mediating variable on the effects of novelty seeking and familiarity on tourist revisit intention
}

\author{
Regina Priya Agustina ${ }^{1}$ and Yessy Artanti ${ }^{2}$ \\ 1,2Department of Management, Faculty of Economics, Universitas Negeri Surabaya
}

Abstract The development of tourism is important for people's lives because it is related to impact on economic, social, cultural and educational developments both nationally and internationally. Therefore, businessman in the tourism sector are expected to be able to maintain good relations with tourists who visit in order to have the revisit intention in the future. The purpose of this study was to analyze and discuss the effects of novelty seeking and familiarity on revisit intention with satisfaction as mediating variable in the city of Surabaya. Data collection method is done by online questionnaire. The sampling technique of this study was nonprobability sampling with judgmental sampling method. Respondents used were 200 respondents who had visited artificial tourist destinations in the city of Surabaya in the last 2 years. Analysis using path analysis showed that novelty seeking had no significant effect on revisit intention, while familiarity and satisfaction had a significant effect on revisit intention. Likewise, both novelty seeking and familiarity significantly influence satisfaction.

\section{INTRODUCTION}

The tourism sector is an industry that can boost a country's economy. In Indonesia, tourism is one of the sectors developed and supported by the government. According to WTTC (2018) Indonesia has become one of the countries with tourism growth in the world in the past seven years with a total score of 14.25 and is ranked 9th out of 30 countries. Therefore, according to data from the Ministry of Tourism (2019), the tourism sector in Indonesia has been established as a leading sector because it has made a significant contribution to the Indonesian economy. The results of the 2018 archipelago tourist survey showed that the number of archipelago tourist trips to East Java Province was the highest, with a number of trips reached $17.96 \%$ and being able to outperform other provinces which every year has increased.

This statement is supported by the data from East Java Culture and Tourism Office (2018) which consists of the cities ranking in East Java that were visited by archipelago tourists in 2017. From these results, Surabaya City is the city in East Java that is visited by most tourist's archipelago. Moreover, based on the Surabaya city number in 2019, the Surabaya city has experienced a significant increase in the number of tourist arrivals since 2013 in amount 11,122,194 million inhabitants till 2018 to $27,575,125$ million inhabitants. And in 2018 and 2019, Surabaya city also received a total of 3 International awards. Although the Surabaya city has increased in the tourism sector since 2018 to 2019 with various improvements and updates in several tourist destinations. But Surabaya city has not been able to improve the ranking of the traveler's city choices, from the second place in 2018 to sixth place in 2019 (tirto.id, 2019). As the tourism market becomes more competitive, the importance of repeat visits from a tourist is also increasing for a tourist destination (Jacoby \& Chestnut, 1978).

According to Hasan (2015), a tourist revisit is an attractive market segment for a destination, mainly because of the cost and effectiveness of the destination event is an important art for the tourism industry. The intention of revisit is an important part of the tourist destination, because it will save more 
costs than attracting the new visitors. In the service industry, satisfaction is considered as "overall evaluation of customer experience with service providers, which opposed to satisfaction assessment of specific transaction" (Han, Back, \& Barrett, 2009). If they are satisfied, they will be more likely to keep coming back. Likewise, if they are not satisfied, they will be more likely to turn to other alternatives (Oliver \& Swan, 1989).

This is consistent with Zikmund's statement in Gaffar (2007) which explains that satisfaction is one of the factors driving loyalty. So that in the marketing context, tourist behavior is related to the image, attitude, perception, satisfaction, choice, motivation, decision making, and so on which related to repurchase or return visit behavior, where tourist satisfaction plays an important role in the structure of consumer behavior models (Hasan, 2015). In the tourism context, there are two different tourist characters. First, allocentric which is someone who is looking for novelty (something new) and it is often to be main motivation for tourists to travel. Second, psychocentric, is for the tourists who like things that are familiar to them and in accordance with the experience which desired by these tourists (Hasan, 2015).

With the tourist's motivation to look for the new things and also prefer to visit in accordance of the experience they had previously felt, tourists will be easier to make purchases or repeat visits to a destination. According to the Shimojo, et al. (2010) research, the separation of novelty and familiarity existed in the preferences assessment, where the number of tourist visits in a tourist place will always be related to the concept of novelty and destination familiarity. Novelty seeking behavior is able to reflect tourist preferences in order to get new experiences and in generally recognized as a stable and consistent personality trait from time to time. While according to Baloglu (2001; in Tan, 2017), destination familiarity is an important topic for tourism research because it represents key marketing variables in segmenting and targeting certain groups also developing marketing action plans, including product decisions, distribution, pricing and promotion.
This study aims to determine the effect of novelty seeking, and familiarity to revisit intenton, and the effect of satisfaction on revisit intention. Therefore, it is hoped that this study can contribute to the businesses in the tourism sector of Surabaya city in development and management of artificial tourism by using the concept of novelty and familiarity that is able to create the intention to the revisit tourists who have previously visited.

\section{LITERATURE REVIEW AND HYPOTHESES DEVELOPMENT}

When travelling, tourists will experience the stages of the visiting decision process, where the next action or experience after the visit is done based on the satisfaction and dissatisfaction of tourists. Some things are becoming tourist stimulants to act can be divided into two, there are internal factors in the form of time, psychological factors such as motivation, attitude, and perception, as well as external factors in the form of destination product, reference group, and destination image (Hidayah, 2019). According to Yoon \& Uysal (2005) for marketing a tourist destination, tourist loyalty to a tourist destination can be considered as their intention to revisit and recommend the destination to others.

\section{Revisit intention}

According to Cole \& Scott (2004), revisit intention is a desire or plan for consumers to make a return visit to the same place. The intention to visit again is an important part of the tourist destination, because the intention to visit again will save more costs than attracting the new visitors. Meanwhile, according to Hasan (2015) tourism marketing orientation which is centered on efforts to maintain visitor loyalty can provide long-term success and increase the sustainability of the destination. Therefore, revisit Intention, conceptually is an intention to continue purchasing (long-term dimension), desire to buy more products (length of stay - longer / short term stay), and the desire to recommend the product to others (long-term dimension) detected from the extent to which tourists perceive the destination as a place recommended by others. 


\section{Satisfaction and revisit intention}

According to Lovelock and Wirtz (2011; in Wulanjani \& Derriawan, 2017), satisfaction is an attitude that is decided based on the experience gained. Meanwhile according to Hasan (2015), satisfaction is the comparison between what is expected with the level of performance felt by tourists. This means that satisfaction is a comparison between performance and expectations, if the perceived product performance is higher than expectations, tourists will be satisfied and happy. Moreover, many researchers have also shown that tourist experience and tourist satisfaction with a purpose are the main determinants of tourist intentions in revisiting a tourist destination (Um, Chon, \& Ro, 2006). According to Roig et al. (2009), there are two approaches used to measure satisfaction, the first is based on specific transactions, and the second is based on overall satisfaction. Specific transactions are described as customer evaluations of consumption experiences and reactions to certain product transactions, episodes, or service meetings, while overall satisfaction (all satisfaction) is described as an overall evaluation of the customer for a product or service provider (Olsen \& Johnson, 2003).

Bosque \& Martín (2008) and Yoon \& Uysal (2005) studies revealed that satisfaction has a significant influence on the revisit intention. However, these results are not in line with the research of Bigné, et al. (2009) which discovered that the satisfaction variable does not significantly influence to the revisit intention in a short period of time. This is also supported by Hasan (2015) who also mentioned that tourists who have felt satisfaction with the destination, there is a possibility that these tourists do not have the intention to return to the same destination in the future. Specific new things will be the reason for repeated visits. So, that the results can be found that satisfaction does not directly correlate with the intention of a tourist return visit (Hasan, 2015).

H5: There is a significant effect of satisfaction on revisit intention

\section{Novelty seeking, revisit intention, and satisfaction}

Novelty seeking behavior has been identified as an important factor which influencing tourist behavior (Mak, 2016).
According to Weiler \& Colin (1992), explains that novelty seeking is the tourist's motivation in the search for objects and tourist attractions that are unique and new. Or seeking or exploiting of new locations that are more challenging for some types of tourist attractions that are observed. Highlevel novelty seekers are referred to as "neophilia" (Greek), which means love for something new. Similarly, as research. Based on research from (Lee \& Crompton, 1992) there are 6 dimensions of novelty seeking, namely changing habits, escape, sensation, adventure, reducing boredom, and surprise.

According to research by Niininen, et al. (2004) found the evidence to support some of the propositions that tourists with a tendency to seek novelty show a variety of destination patterns and therefore tend to return to the same destination. This finding is also supported by research from Jang \& Feng (2007) which focuses on the intention to revisit a destination from a temporal perspective, analyzing the effects of seeking for novelty and satisfaction in short, medium, and long-term revisit intentions. These findings reveal that the seeking for novelty directly affects the intention of the mediumterm revisit and indirectly will also affects the intention of the long-term revisit through the medium-term revisit intention. However this is not in line with the research from (Assaker et al., 2011); (Bignè et al., 2009)) which explaining if tourists with a higher tendency to seek novelty in their vacation destinations show a lower intention to revisit not only on the next trip, but also in the intention of revisit in the future. Besides that, Toyama \& Yamada (2012) research found that only novelty seeking which can influence the formation of a tourist satisfaction variable. According to research from Assaker et al. (2011), both novelty seeking and satisfaction are the two variables that most influence the intention to revisit. This is also supported by Hasan (2015) who states that the direct effect of novelty on satisfaction has a significant effect on tourist destinations and the intention to revisit.

\section{H1: There is a significant effect of novelty seeking on revisit intention}

H3: There is a significant effect of novelty seeking on satisfaction 
Table 1.

Measurements

\begin{tabular}{|c|c|c|}
\hline Variable & Researcher & Item Statement \\
\hline Novelty seeking & $\begin{array}{l}\text { Jang \& Feng (2007); } \\
\text { Assaker et al. (2011); } \\
\text { Toyama \& Yamada } \\
(2012)\end{array}$ & $\begin{array}{l}\text { This destination offering the new experience } \\
\text { This destination offering the new things } \\
\text { Experiencing the culture, local handicraft, and the result of } \\
\text { difference creation } \\
\text { Interesting and friendly local people } \\
\text { Opportunities to increase someone knowledge of place, } \\
\text { people, and etc. }\end{array}$ \\
\hline Familiarity & $\begin{array}{l}\text { Milman \& Pizam } \\
\text { (1995); Toyama \& } \\
\text { Yamada (2012) }\end{array}$ & $\begin{array}{l}\text { More knowledges of the tourist destination in general } \\
\text { Knowing more than anyone else about this destination } \\
\text { This destination feels familiar for me } \\
\text { Perecise accuration of destination geography }\end{array}$ \\
\hline Satisfaction & $\begin{array}{l}\text { Jang \& Feng (2007); } \\
\text { Roig et al. (2009); Ha } \\
\text { \& Jang (2010) }\end{array}$ & $\begin{array}{l}\text { Reasonable cost } \\
\text { Expectations fulfilled } \\
\text { Overall satisfaction }\end{array}$ \\
\hline Revisit intention & $\begin{array}{l}\text { Jang \& Feng (2007); } \\
\text { Assaker, et al. (2011); } \\
\text { Toyama \& Yamada } \\
\text { (2012) }\end{array}$ & $\begin{array}{l}\text { Intuition to revisit } \\
\text { The possibility of returning to the destination for your next } \\
\text { trip } \\
\text { The possibility of returning to the destination in the future }\end{array}$ \\
\hline
\end{tabular}

\section{Familiarity, revisit intention, and satisfaction}

Several studies have attempted to identify factors that influence destination loyalty. For example, previous research revealed the effects of satisfaction, destination image, motivation, etc. However, several studies have investigated the effect of destination familiarity, which plays an important role in the tourist perception of Milman \& Pizam (1995; in Toyama \& Yamada, 2012). According to Baloglu (2001), explains that "familiarity with a destination is a significant concept for tourist destinations because of its vital role in tourist destination selection process," which means that familiarity with a destination is an important concept for a tourist destination. This is due to its vital role in the process of selecting a tourist destination. Moreover, the tourists who feel familiar and like things that are generally known to a destination then they will have the willingness to make purchases or revisit in the future.

This is supported by research of Milman \& Pizam (1995) which shows that familiarity has a significant influence on future revisit intention. These results are consistent with $\mathrm{Ha}$ \& Jang (2010), which explains that customers who are more familiar with a tourist destination must be accustomed to not only to the food, but also the atmosphere of the destination. However, according to the research by Toyama \& Yamada (2012), the relationship between familiarity with satisfaction is not significant. This shows that tourists who feel familiar with a tourist destination can provide a feeling of security and comfort, which can lead to the loyalty of these tourists.

H2: There is a significant effect of between familiarity on revisit intention

H4: There is a significant effect of familiarity on satisfaction

\section{METHODS}

This study were quantitative in nature and attempted to examine hypotheses as captured in figure 1. The sampling method used is the non-probability sampling technique using judgmental sampling. The distribution of questionnaires was done by

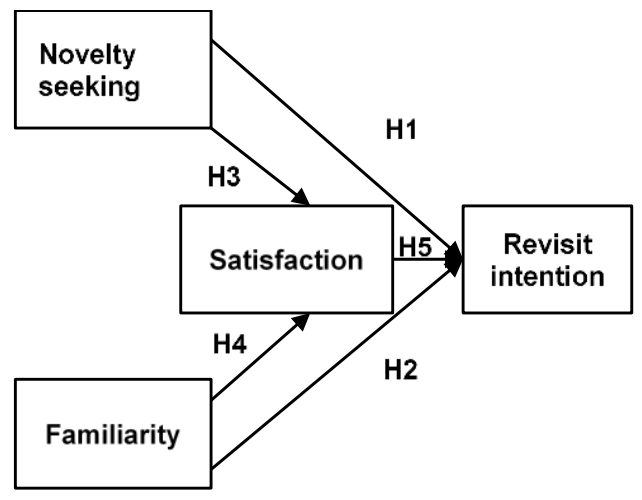

Figure 1.

Conceptual Framework 
Table 2.

Validity and reliability test results

\begin{tabular}{|c|c|c|c|c|}
\hline $\begin{array}{c}\text { Item } \\
\text { Statement }\end{array}$ & $r$ count & Validity & $\begin{array}{c}\text { Cronbach's } \\
\text { Alpha }\end{array}$ & Reliability \\
\hline \multicolumn{5}{|c|}{ Novelty seeking (X1) } \\
\hline$X 1.1$ & 0,790 & Valid & \multirow{6}{*}{0,890} & \multirow{6}{*}{ Reliable } \\
\hline $\mathrm{X} 1.2$ & 0,702 & Valid & & \\
\hline $\mathrm{X} 1.3$ & 0,720 & Valid & & \\
\hline $\mathrm{X} 1.4$ & 0,803 & Valid & & \\
\hline $\mathrm{X} 1.5$ & 0,665 & Valid & & \\
\hline $\mathrm{X} 1.6$ & 0,611 & Valid & & \\
\hline \multicolumn{5}{|c|}{ Familiarity (X2) } \\
\hline X2.1 & 0,712 & Valid & \multirow{4}{*}{0,813} & \multirow{4}{*}{ Reliable } \\
\hline X2.2 & 0,452 & Valid & & \\
\hline X2.3 & 0,713 & Valid & & \\
\hline X2.4 & 0,690 & Valid & & \\
\hline \multicolumn{5}{|c|}{ Satisfaction (Z) } \\
\hline $\mathrm{Z1.1}$ & 0,755 & Valid & \multirow{3}{*}{0,725} & \multirow{3}{*}{ Reliable } \\
\hline $\mathrm{Z} 1.2$ & 0,416 & Valid & & \\
\hline Z1.3 & 0,571 & Valid & & \\
\hline \multicolumn{5}{|c|}{ Revisit intention (Y) } \\
\hline Y1.1 & 0,589 & Valid & \multirow{3}{*}{0,716} & \multirow{3}{*}{ Reliable } \\
\hline Y1.2 & 0,481 & Valid & & \\
\hline Y1.3 & 0,587 & Valid & & \\
\hline
\end{tabular}

online using google form to 200 respondents who had been adjusted to the characteristic's limitations of research respondents. Where the characteristics of the respondent is someone who has visited an artificial tourist destination in the Surabaya city in the past 2 years and is an archipelago tourist with an age range of 15 54 years old. The data analysis technique used is the path analysis technique (path analysis).

Table 1 explains the measurement items of the variables that used to measure novelty seeking, familiarity, satisfaction, and revisit intention that have been used by several researchers before and adopted by researchers. In table 1 , it is already mentioned about several statement items that are used to measure this study variables. Measurement on these variables is done by combining indicators from several previous studies. To measure it by using a 5 point Likert scale $(1=$ strongly disagree, up to, $5=$ strongly agree.

\section{RESULTS AND DISCUSSION}

Before analyzing the data, the researchers distributed online questionnaires to 30 respondents outside the research respondents to conduct validity and reliability tests. Based on the results of the validity test that has been done, all statement item that being used are said to be valid, because the value of $r$ count $>$ 0.361 and is significant. As for the reliability test results showed the value amount of Cronbach's Alpha for novelty seeking, familiarity, satisfaction, and revisit intention $>0.70$. So, it is found that the statements on the research instrument (questionnaire) are reliable. The results of the validity and reliability tests have been summarized by researcher in Table 2.

To collect data, we distributed research questionnaires to 220 respondents on social media such as Instagram, WhatsApp, Line, and Facebook. Based on a questionnaire that has been distributed online, researchers collected the data of 200 respondents who were in accordance with the limitations of the study. Characteristics of research respondents are presented in table 3

As showed in table 3, it can be seen that the majority of respondents are female with

Table 3.

Respondent characteristics

\begin{tabular}{|c|c|c|}
\hline \multicolumn{2}{|c|}{ Respondent characteristics } & $(\%)$ \\
\hline \multirow{4}{*}{ Age } & $15-25$ & $89 \%$ \\
\hline & $26-35$ & $8,5 \%$ \\
\hline & $36-45$ & $2,5 \%$ \\
\hline & $46-54$ & - \\
\hline \multirow{2}{*}{ Gender } & Male & $29 \%$ \\
\hline & Female & $71 \%$ \\
\hline \multirow{5}{*}{ Visiting } & 1 time & $20,5 \%$ \\
\hline & 2 times & $31 \%$ \\
\hline & 3 times & $21 \%$ \\
\hline & 4 times & $11,5 \%$ \\
\hline & 5 times & $16 \%$ \\
\hline \multirow{5}{*}{$\begin{array}{l}\text { Profes } \\
\text { sion }\end{array}$} & Others & $3,5 \%$ \\
\hline & Government Employee & $2 \%$ \\
\hline & Private Employee & $22,5 \%$ \\
\hline & Student / College & $64,5 \%$ \\
\hline & Entrepreneur & $7,5 \%$ \\
\hline \multirow{6}{*}{$\begin{array}{l}\text { Income } \\
\text { per } \\
\text { month }\end{array}$} & $<\mathrm{Rp} 1.000 .000$ & $50,5 \%$ \\
\hline & $\begin{array}{l}R p 1.000 .001-R p \\
2000000\end{array}$ & $8,5 \%$ \\
\hline & Rp 2.000.001-Rp & $105 \%$ \\
\hline & 3.000 .000 & $19,5 \%$ \\
\hline & $\begin{array}{l}\text { Rp 3.000.001-Rp } \\
4.000 .000\end{array}$ & $10,5 \%$ \\
\hline & $>\operatorname{Rp} 4.000 .000$ & $11 \%$ \\
\hline
\end{tabular}


an age range of 15-25 years old, who work as students / college students and have an income of less than Rp 1,000,000, and have visited artificial tourist destinations in the Surabaya city as much as 2 times in the last 2 years (2018 - 2019). These results can be concluded that respondents with these criteria are more interested in visiting artificial tourist destinations in Surabaya city, this is caused by the respondents with age and type of work still have a lot of free times to make visits, as well as tickets from each destination also included cheap. Moreover, the female respondents also prefer to hangout or travel to the same destination compared to male respondents, because according to them the tourist destination has the photo spots and also new vehicles that are beautiful and can be captured with good photo.

To examine our hypotheses, we conducted a path analysis test which the results are showed in table 4 . Based on table 4, it was suggested that $\mathrm{H} 2, \mathrm{H} 3, \mathrm{H} 4$, and $\mathrm{H} 5$ were supported because they had a calculated $\mathrm{CR}$ value $>2.00$ and a significance value $(P)<0.05$. However, $H 1$ was not supported because the calculated $\mathrm{CR}$ value $<2.00$ and the significance value $(P)>0.05$. Besides, based on the overall results of the standardized direct effects, standardized indirrect effects, and standardized total effects, the obtained values from the standardized direct effects novelty seeking (X1) and familiarity (X2) on satisfaction (Z) are greater than the value of the direct influence of the novelty seeking variable (X1) and familiarity (X2) towards revisit intention $(Y)$. This suggested that the satisfaction cannot be a stand-alone variable and becomes a mediating variable or it can be said also that the satisfaction variable cannot be an independent variable.

Mediation test results from this study suggested that satisfaction mediated the effect of novelty seeking on revisit intention and partially mediated the effect of familiarity on revisit intention. This result is due to the influence of the novelty seeking on revisit intention which significant with a value of 0.130 . Then, after adding the satisfaction variable, the value of the effect of novelty seeking on revisit intention decreased by 0.019 almost close to 0,000 and the effect of the familiarity on the revisit intention is significant with a value of 0.354 . Then, after adding the satisfaction variable, the value of the effect of the familiarity on revisit intention decreased but it is not equal to zero which is equal to 0.165 .

According to Assaker, et al. (2011), novelty seeking is a level of contrast between current perceptions and past experiences in traveling, so that tourists have a new destination in future trips. In relation to research conducted on artificial tourist destinations in the Surabaya city, such behavior is the same as the motivation of a tourist who wants to find the novelty of a destination. This explanation is in line with the Surabaya city government expectations who wants tourists not only visit Surabaya once by starting to make efforts to update and repair several tourist sites. Such as creating the Suro and Boyo Giant Statue in the Kenjeran Park area and also the renewal concepts in the Surabaya Carnival Park tourist destination which has better and unique photo spots that are currently favored by tourists. The updates and changes are also in accordance to the results of the description of the highest respondent's answer for novelty seeking, that is "I found something new (photo spot, new vehicle, sculptures, etc.) from artificial tourist destinations in the Surabaya city that I had previously visited". However, this study found that novelty seeking had no effect on Revisit intention. The results of this study are consistent with the Assaker et al. (2011) \& Bigné et al. (2009) research which says that Novelty seeking is not significant to intention of visit again (revisit intention). This means that although Surabaya city has made many updates and improvements in several artificial tourist locations, it does not affect tourists in determining their intention to revisit in the short or long term. These results indicate that the first hypothesis which is "there is a significant influence between the novelty seeking on revisit intention the tourists of Surabaya city" is not supported.

Furthermore, the relationship of familiarity to revisit intention has a significant effect. This means that if a tourist feels familiar with an artificial tourist destination in the Surabaya city that they have previously visited, it will affect the intention of a revisit from the tourist both in the short-term or in the future. So, the second hypothesis which is "there is a significant influence between the familiarity on revisit intention the tourists of the Surabaya city" is supported. The results of this study also support the research by Milman \& Pizam (1995) and Mechinda et al. (2009) which shows that 
there is a significant influence between familiarity on revisit intention. Hasan (2015) in his book explained that tourists who feel familiar and like things that are generally known about a destination, will have the willingness to make purchases or revisit to the destination. The explanation is in accordance with the description results of the highest respondent's answer to familiarity, "I know in general about artificial tourist destinations in the Surabaya city that I will visit again". As well as various efforts undertaken by the Surabaya city government such as the creation of the Stacked Bus (Mayapada) and the Surabaya bus which is become one of the Surabaya's tourist transportation, where besides of a unique payment system that is exchanging plastic bottle bins for payment, this bus also provided for tourists who want to travelling around the Surabaya city in an easier, safer and more convenient way. So that when they visited and boarded the tour bus, they become more familiar with tourist destinations in the Surabaya city and have the intention to revisit in near-term or in the future.

Then the novelty seeking relationship to satisfaction shows the results that there is a significant effect. So, the third hypothesis which states "there is an influence between the novelty seeking variables to the satisfaction of tourists in Surabaya city" is supported. This means that if a tourist has a desire to explore or look for new things (novelty seeking) from an artificial tourist destination in the Surabaya city, it will affect the satisfaction of these tourists. If the new things in the artificial tourist destination are in accordance with their expectations, then tourists will feel satisfied, and vice versa. The results of this study are supported by research from Toyama \& Yamada (2012) and Assaker et al. (2011) which shows that there is a significant influence between novelty seeking on satisfaction. Hasan (2015) in his book also explained that the direct effect of novelty on satisfaction had a significant influence on tourist destinations and the intention to revisit. In relation to artificial tourist destinations in Surabaya city, tourists who visit artificial destinations in Surabaya city and found something new such as photo spot or new vehicle will feel a sense of satisfaction because they feel it is not in vain to have visited and the possibility of these tourists have the intention to revisit to the destination in the future.
For the relationship of familiarity to satisfaction, the results show that there is a significant influence. This means that if tourists already feel familiar with artificial tourist destinations in the Surabaya city that they have previously visited, it will affect the satisfaction of these tourists. These results indicate that the third hypothesis which states "there is a significant influence between the familiarity on the satisfaction of tourists in the Surabaya city" is supported. But these results are not in line with research from Toyama \& Yamada (2012) which showed that the relationship between familiarity with satisfaction is not significant. In relation to the results of this study that show familiarity (familiar) has a significant influence on satisfaction in accordance with the state of tourism in the Surabaya city. This is proved by an increase in the number of tourist visits each year (BPS Surabaya city, 2019), and since 2018 the government of Surabaya city began to innovate by decorating the roads and parks in several corners of the Surabaya city using decorative lights and also some photo spots that able to attract the attention of tourists who pass or visit the streets and parks of the city. Through these innovations, the tourists who visit the streets or city parks will feel satisfied and make the experience of visiting the Surabaya city become more meaningful and able to help the tourists feel more familiar with tourist destinations in the Surabaya city.

Last, the relationship of satisfaction towards revisit intention showed that there is a significant influence. This means that if a tourist feels satisfied with their visit to an artificial tourist destination in the Surabaya city, it will affect the revisit intention or intention to visit again from the tourist both in the near-term or in the future. The results of this study supporting the research of (Yoon \& Uysal, 2005; Assaker et al. 2011; Toyama \& Yamada, 2012; and Eusebio \& Vieira, 2012) which shows that there is a significant influence between satisfaction with Revisit intention. This is also consistent with Zikmund's statement in Gaffar (2007: 71) which explains that satisfaction is one of the factors driving loyalty. So that in the context of marketing, tourist behavior related to image, attitude, perception, satisfaction, motivation, decision making, and so on related to repurchase or revisit behavior, tourist satisfaction plays one important role in the structure of the consumer behavior 
model (Hasan, 2015). The theory supports the results of respondents' answers from this study which shows the highest statement items are tourists feeling satisfied and at the same time happy when visiting artificial tourist destinations in the Surabaya city. Another thing that makes tourists feel satisfied when visiting artificial tourist destinations in the Surabaya city is the entrance ticket price that is fairly cheap so that tourists do not hesitate to revisit the artificial tourist destinations in Surabaya city in the future.

\section{CONCLUSION}

This study proves that there is no significant influence between the desire to look for new things or novelty seeking on revisit intention or intention to tourists' revisit in tourist destinations which made in Surabaya. However, this study proves that familiarity or intimacy and satisfaction significantly influences the revisit intention of tourists to artificial tourist destinations in the Surabaya city. This proves that many tourists visiting tourist destinations which made in Surabaya city who feel familiar with a destination have more intention to return to the destination compared to tourists who only look for the new things from a destination. Furthermore, the results of the study also showed that novelty seeking and familiarity had a significant effect on satisfaction. Besides that, satisfaction is also proven to be able to mediate between the novelty seeking variables with revisit intention perfectly, and partially mediate the familiarity with the revisit intention. Based on the results of this study, it certainly does not escape from the shortcomings and mistakes, so the researcher suggested if further research is done by using the same variable is expected to be able to add the literature regarding the related variables, there are novelty seeking and familiarity. So, the research can be done more optimally. As well as for further research it is also expected to be able used the other independent variables that are able to influence revisit intention beyond the variables that being used in this study because the contribution given is only $53 \%$ while the remaining $47 \%$ is explained by other variables. Other variables that can be used can originate from inside or outside the individual.

\section{REFERENCES}

Assaker, G., Esposito, V., \& Connor, P. O. (2011). Examining the effect of novelty seeking, satisfaction, and destination image on tourists ' return pattern: A two factor, non-linear latent growth model. Tourism Management, 32(4), 890-901.

Baloglu, S. (2001). Image variations of Turkey by familiarity index: informational and experiential dimensions. Tourism Management, 22(2), 127-133.

Berkowitz, E. N., Jacoby, J., \& Chestnut, R. (1978). Brand Loyalty: Measurement and Management. Journal of Marketing Research, doi:10.2307/3150644. Journal of Marketing Research, 15(4), 659-660.

BPS Kota Surabaya. (2019). Kota Surabaya Dalam Angka 2019. Surabaya: Badan Pusat Statistik Kota Surabaya.

Cole, S. T., Scott, D., \& Cole, S. T. (n.d.). Examining the Mediating Role of Experience Quality in a Model of Tourist Experiences Examining the Mediating Role of Experience Quality in a Model of Tourist Experiences. (February 2014), 37-41.

del Bosque, I. R., \& San Martín, H. (2008). Tourist satisfaction a cognitive-affective model. Annals of Tourism Research, 35(2), 551-573.

Dinas Pariwisata dan Budaya Jawa Timur. (2018). Rakernis Kadisbudpar Jatim 2018.

Enrique Bigné, J., Sánchez, I., \& Andreu, L. (2009). The role of variety seeking in short and long run revisit intentions in holiday destinations. International Journal of Culture, Tourism and Hospitality Research, 3(2), 103-115.

Eusebio \& Vieira. (2012). Segmenting Mainland Chinese Tourists to. 352(July 2011), 339-352.

Gaffar Vanessa. (2007). Customer Relationship Management and Marketing Public Relations (1st ed.). Bandung: Alfabeta.

Ha, J., \& (Shawn) Jang, S. C. (2010). Perceived values, satisfaction, and behavioral intentions: The role of familiarity in Korean restaurants. International Journal of Hospitality Management, 29(1), 2-13.

Han, H., Back, K. J., \& Barrett, B. (2009). Influencing factors on restaurant customers' revisit intention: The roles of emotions and switching barriers. 
International Journal of Hospitality Management, 28(4), 563-572.

Hasan, A. (2015). Tourism Marketing (T. CAPS, Ed.). Yogyakarta: CAPS (Center For Academic Publishing Service).

Hidayah Nurdin. (2019). Pemasaran Destinasi Pariwisata (1st ed.). Palembang: Alfabeta.

Jang, S. C., \& Feng, R. (2007). Temporal destination revisit intention: The effects of novelty seeking and satisfaction. Tourism Management, 28(2), 580-590.

Kemenpar. (2019). Laporan Akuntabilitas Kinerja Kementerian Pariwisata 2018. 53(9), 1689-1699.=

Lee, T., \& Crompton, J. (1992). Measuring Novelty In Tourism Seeking. 19, 732751.

Mak, A. (2016). Novelty, tourism *. (March).

Mechinda, P., Serirat, S., \& Gulid, N. (2009). An examination of tourists' attitudinal and behavioral loyalty: Comparison between domestic and international tourists. Journal of Vacation Marketing, 15(2), 129-148.

Milman, A., \& Pizam, A. (1995). The Role of Awareness and Familiarity with a Destination: The Central Florida Case. Journal of Travel Research, 33(3), 2127.

Niininen, O., Szivas, E., \& Riley, M. (2004). Destination loyalty and repeat behaviour: an application of optimum stimulation measurement. International Journal of Tourism Research, 6(6), 439447.

Oliver, R. L., \& Swan, J. E. (1989). Consumer Perceptions of Interpersonal Equity and Satisfaction in Transactions: A Field Survey Approach. Journal of Marketing, 53(2), 21.

Olsen, L. L., \& Johnson, M. D. (2003). Service Equity, Satisfaction, and Loyalty: From Transaction-Specific to Cumulative Evaluations. Journal of Service Research, 5(3), 184-195.

Press, Y. H., Weiler, B., \& Hall, C. M. (2015). Review.

Roig, J. C. F., García, J. S., \& Tena, M. Á. M. (2009). Perceived value and customer loyalty in financial services. Service Industries Journal, 29(6), 775-789.

Shimojo, Park, J.,, E., \& Shimojo, S. (2010). Roles of familiarity and novelty in visual preference judgments are segregated across object categories. Proceedings of the National Academy of Sciences of the United States of America, 107(33), 14552-14555.

Tan, W. K. (2017). Repeat visitation: A study from the perspective of leisure constraint, tourist experience, destination images, and experiential familiarity. Journal of Destination Marketing and Management, 6(3), 233-242.

Tirto.id. (2019). daftar 10 kota wisata indonesia terpopuler 2019 versi tripadvisor. Diakses pada: 12 Maret 2020.

Toyama, M., \& Yamada, Y. (2012). The Relationships among Tourist Novelty, Familiarity, Satisfaction, and Destination Loyalty: Beyond the Novelty-familiarity Continuum. International Journal of Marketing Studies, 4(6), 10-18.

Um, S., Chon, K., \& Ro, Y. H. (2006). Antecedents of revisit intention. Annals of Tourism Research, 33(4), 11411158.

WTTC. (2017). Travel \& Tourism Power and Performance Report. Diakses pada: 19 November 2019

Wulanjani, H., \& Derriawan, D. (2017). Dampak Utilitarian Value Dan Experiential Marketing Terhadap Customer Satisfaction Dan Revisit intention. Jurnal Riset Manajemen Dan Bisnis (JRMB) Fakultas Ekonomi UNIAT, 2(2), 121130.

Yoon, Y., \& Uysal, M. (2005). An examination of the effects of motivation and satisfaction on destination loyalty: A structural model. Tourism Management, 26(1), 45-56. 